Original Research Paper

\title{
Pemanfaatan Limbah Organik (Kotoran Sapi) Menjadi Biogas dan Pupuk Kompos
}

\author{
Lalu Ali Wardana ${ }^{*}$, Nizar Lukman ${ }^{2}$, Mukmin ${ }^{3}$, Muhibban Sahbandi ${ }^{4}$, Mario Sakti Bakti ${ }^{5}$, Deninta Wasim \\ Amalia $^{6}$, Ni Putu Ayu Wulandari ${ }^{5}$, Diana Afrianita Sari ${ }^{5}$, Cornelius Sopar Nababan ${ }^{7}$ \\ ${ }^{\text {I} P r o g r a m ~ S t u d i ~ P e n d i d i k a n ~ B a h a s a ~ I n g g r i s, ~ F a k u l t a s ~ K e g u r u a n ~ d a n ~ I l m u ~ P e n d i d i k a n, ~ U n i v e r s i t a s ~ M a t a r a m, ~ M a t a r a m, ~}$ \\ Indonesia \\ ${ }^{2}$ Program Studi Hubungan Internasional, Universitas Mataram, Mataram, Indonesia \\ ${ }^{3}$ Program Studi Teknik Sipil, Fakultas Teknik, Universitas Mataram, Mataram, Indonesia \\ ${ }^{4}$ Program Studi Teknologi Pangan, Fakultas Teknologi Pangan dan Agroindustri, Universitas Mataram, Mataram, Indonesia \\ ${ }^{5}$ Program Studi Manajemen, Fakultas Ekonomi, Universitas Mataram, Mataram, Indonesia \\ ${ }^{6}$ Program Studi Ilmu Tanah, Fakultas Pertanian, Universitas Mataram, Mataram, Indonesia \\ ${ }^{7}$ Program Studi Agribisnis, Fakultas Pertanian, Universitas Mataram, Mataram, Indonesia
}

https://doi.org/10.29303/jpmpi.v3i2.615

Sitasi: Wardana, L. A., Lukman, N., Mukmin., Sahbandi, M., Bakti, M. S., Amalia, D. W. Wulandari, N. P. A., Sarri, D. A., \& Nababan, C. S (2021). Pemanfaatan Limbah Organik (Kotoran Sapi) Menjadi Biogas dan Pupuk Kompos. Jurnal Pengabdian Magister Pendidikan IPA, 4(1)

Article history

Received: 05 Desember 2020

Revised: 30 Desember 2020

Accepted: 08 Februari 2021

*Corresponding Author: Lalu Ali Wardana, Program Studi Pendidikan Bahasa Inggris, Fakultas Keguruan dan Ilmu Pendidikan, Universitas

Mataram, Mataram, Indonesia; Email:

aliwardana@unram.ac.id

\begin{abstract}
Masalah energi telah menjadi masalah yang cukup rumit dan sukar dihadapi terutama mengenai energi tak terbarukan yang sangat diperlukan dalam kehidupan manusia. Oleh karena itu, diperlukan sebuah inisiasi yang dapat mengurangi ketergantungan masyarakat terhadap energi tak terbarukan tersebut. Salah satunya energi yang yang suatu saat akan habis adalah gas, gas diperlukan sebagai bahan bakar tidak hanya di kehidupan rumah tangga melainkan seluruh aktivitas manusia. Maka adapun inisiasi untuk mengakali penggunaan gas bumi dengan memanfaatkan limbah kotoran sapi untuk dijadikan sebagai biogas yang dapat meringankan beban masyarakat serta menghemat energi. Selain itu limbah kotoran sapi pula dapat dijadikan pupuk kompos yang sangat berguna dalam meregenerasi tanah. Tentunya inisiasi ini sangat bermanfaat bagi kehidupan umat manusia.
\end{abstract}

Keywords: Energi; Gas bumi; Kotoran sapi (ternak); Biogas; Pupuk Kompos.

ekspornya. Di lain sisi ketersedian cadangan energi fosil berupa gas dan minyak yang terbatas tidak sebanding dengan peningkatan kebutuhan energi. Memang tidaklah terlalu buruk bagi kita untuk bergantung dengan sumber energi fosil namun juga perlu dipikirkan bahwa energi fosil akan habis beberapa dasawarsa lagi. Karena itu, akhirnya mendorong banyak ilmuwan untuk mencari sumber energi alternatif baru untuk menggantikan sumber energi fosil. Energi terbarukan menjadi cukup penting sehingga membuat kestabilan energi tetap terjaga. Dalam hal ini dapat dicontohkan yaitu bahan bakar gas yang dibutuhkan dalam kehidupan rumah tangga, setiap masyarakat membutuhkan gas untuk memasak, hal ini kemudian menjadi 
tantangan dimana selain harganya yang cukup mahal, gas juga merupakan energi tak terbarukan sehingga dibutuhkan sebuah inisiasi pengganti bahan bakar gas tersebut.

Kotoran sapi kebanyakan hanya dimanfaatkan untuk dijadikan pupuk kandang namun tanpa proses pengolahan. Biasanya kotoran sapi itu hanya dibiarkan mengering di suatu lahan dan setelah kering baru digunakan untuk penyuburan tanah atau tanaman. Kondisi ini tentu dapat merusak lingkungan, terutama pencemaran udara. Sebab kotoran sapi yang masih basah menimbulkan bau tidak sedap. Ini jelas membahayakan kesehatan bagi orang yang menghirupnya. Padahal jika dianalisis kotoran sapi itu sebenarnya dijadikan bahan dasar dalam pembuatan biogas dan pupuk organik. Biogas merupakan gas yang dihasilkan oleh aktivitas anaerobik atau fermentasi dari bahan-bahan organik termasuk di antaranya; kotoran manusia dan hewan, limbah domestik (rumah tangga), sampah biodegradable atau setiap limbah organik yang biodegradable dalam kondisi anaerobik. Kandungan utama dalam biogas adalah metana dan karbon dioksida Biogas sangat berpotensi untuk dimanfaatkan menjadi sumber energi terbarukan. Hal ini dikarenakan kandungan gas metana $\left(\mathrm{CH}_{4}\right)$ yang tinggi dan nilai kalornya yang cukup tinggi yaitu berkisar antara 4.800-6.700 kkal/ $\mathrm{m}^{3}$. Dimana gas metana hanya memiliki satu karbon di setiap rantainya yang membuat pembakarannya lebih ramah lingkungan, hal intentunya merupakan inisiasi yang sangat dibutuhkan dalam masyarakat dimana dapat menciptakan energi terbarukan sendiri serta dapat bernilai ekonomis. Selain biogas Kotoran sapi juga dapat diolah menjadi pupuk Organik. Pupuk Organik merupakan pupuk yang berasal dari sisa tanaman dan kotoran hewan yang telah mengalami proses dekomposisi atau pelapukan. Selama ini sisa tanaman dan kotoran hewan tersebut belum sepenuhnya dimanfaatkan sebagai pengganti pupuk buatan. Kompos yang baik adalah yang sudah cukup mengalami pelapukan dan dicirikan oleh warna yang sudah berbeda dengan warna bahan pembentuknya, tidak berbau, kadar air rendah dan sesuai suhu ruang. Hal ini pun bisa dikatakan memberikan dampak yang sangat positif yang mana kotoran sapi tidak hanya sia-sia namun memberikan keuntungan.

\section{Metode}

Program ini menggunakan pendekatan kualitatif deskriptif dengan menampilkan gambaran secara detail tentang suatu situasi serta data yang dikumpulkan berupa berupa kata kata atau gambar dan bukan angka. Pengambilan data dilakukan melalui observasi, wawancara dan kajian pustaka yang selanjutnya dianalisis untuk menarik sebuah kesimpulan.

\section{Hasil dan Pembahasan}

\section{a. Pemanfaatan Kotoran Sapi Menjadi Biogas}

Biogas merupakan gas yang dihasilkan oleh aktivitas anaerobik atau fermentasi dari bahanbahan organik termasuk di antaranya; kotoran manusia dan hewan, limbah domestik (rumah tangga), sampah biodegradable atau setiap limbah organik yang biodegradable dalam kondisi anaerobik. Kandungan utama dalam biogas adalah metana dan karbon dioksida Biogas sangat berpotensi untuk dimanfaatkan menjadi sumber energi terbarukan. Hal ini dikarenakan kandungan gas metana $\left(\mathrm{CH}_{4}\right)$ yang tinggi dan nilai kalornya yang cukup tinggi yaitu berkisar antara 4.800-6.700 $\mathrm{kkal} / \mathrm{m}^{3}$. Dimana gas metana hanya memiliki satu karbon di setiap rantainya yang membuat pembakarannya lebih ramah lingkungan. Biogas merupakan gas yang tidak berwarna, tidak berbau dan sangat tinggi dan cepat daya nyalanya. Biogas dapat digunakan sebagai bahan bakar kendaraan maupun untuk menghasilkan listrik ataupun untuk pengganti gas elpiji. Penggunaan biogas memiliki keselamatan yang lebih aman jika dibandingkan dengan gas elpiji. Misalnya jika pipa atau penampung gas bocor tidak akan terjadi ledakan karena gas yang keluar akan menguap dengan cepat dan jika api didekatkan ke sumber gas maka tidak akan terjadi semburan api yang menyebabkan kebakaran. Sehingga biogas kotoran sapi ini dapat dikatakan bahan bakar yang aman. Selain itu biogas juga dapat dimanfaatkan sebagai sumber energi untuk membangkitkan listrik. Sisa kotoran sapi yang digunakan untuk menghasilkan biogas juga dapat digunakan sebagai pupuk organik untuk budidaya tanaman atau kegiatan pertanian. Biogas sangat bagus bagi kelestarian lingkungan dan membuat lingkungan menjadi lebih bersih karena pemanfaatan limbah yang biasanya hanya terbuang sia sia dan hanya mencemari lingkungan namun 
dengan teknik tertentu dapat dijadikan biogas yang dapat bermanfaat. Biogas dapat menghemat biaya operasional rumah tangga contohnya pemanfaatan biogas sebagai bahan bakar minyak lebih hemat ketimbahan bahan bakar lainnya misalnya bahan bakar gas. Biogas dapat dijadikan sebagai bahan bakar pembangkit listrik untuk menggantikan bahan bakar solar sebagai pembangkit listrik.

Proses pembuatan biogas dari kotoran sapi terjadi karena adanya dekomposisi bahan organik secara anaerob (tertutup dari udara bebas). Proses ini akan menghasilkan suatu gas yang sebagian besar mengandung metana dan karbondioksida $\left(\mathrm{CO}_{2}\right)$. Gas yang terbentuk disebut gas rawa atau biogas. Biogas yang terbentuk dapat dijadikan sebagai bahan bakar, karena mengandung gas metana $\left(\mathrm{CH}_{4}\right)$ yang mudah terbakar. Dimana proses pembusukan anaerob yang terjadi dibantu oleh sejumlah mikroorganisme seperti bakteri metan.Suhu yang baik untuk proses fermentasi adalah berkisar antara $25-55^{\circ} \mathrm{C}$. Saat suhu tersebut, mikroorganisme dapat bekerja secara optimal untuk merombak bahan-bahan organik. Komposisi gas yang terdapat pada pembentukan biogas, seperti ditunjukkan pada tabel di bawah ini.

\begin{tabular}{|l|c|}
\hline \multicolumn{1}{|c|}{ Jenis Gas } & Jumlah (\%) \\
\hline Metana $\left(\mathrm{CH}_{4}\right)$ & $54-70$ \\
\hline Karbon dioksida $\left(\mathrm{CO}_{2}\right)$ & $27-45$ \\
\hline Nitrogen $(\mathrm{N})$ & $0,5-3$ \\
\hline Karbon monoksida $(\mathrm{CO})$ & 0,1 \\
\hline Oksigen $\left(\mathrm{O}_{2}\right)$ & 0,1 \\
\hline Hidrogen sulfida $\left(\mathrm{H}_{2} \mathrm{~S}\right)$ & Sedikit sekali \\
\hline
\end{tabular}

Bangunan utama dari cara membuat biogas dari kotoran sapi untuk instalasi biogas yaitu digester yang fungsinya untuk menampung gas metana dari hasil yang diperoleh dari perombakan bahan-bahan organik yang disebabkan oleh bakteri. Besar kecilnya ukuran digester terlihat dari kotoran sapi yang dihasilkan dan seberapa banyak biogas yang diinginkan. Sebaiknya lokasi dimana akan membangun sebuah digester itu harus berdekatan dengan kandang sapi tersebut supaya kotoran sapi tersebut akan mudah untuk disalurkan ke dalam digester sehingga dapat meringankan proses pembuatan biogas. Pada samping digester bangunlah sebuah penampung lumpur, penampung lumpur ini nantinya dipisahkan dan bisa diolah untuk dijadikan pupuk organik padat dan cair.
Adapun langkah-langkah pembuatan biogas menggunakan kotoran sapi sebagai berikut:

1. Mencampur kotoran sapi secukupnya dengan air yang telah ditentukan banyaknya terus diaduk sehingga akan terbentuk seperti lumpur dengan suatu perbandingan 2:1 pada bak yang akan digunakan untuk menampung sementara.

2. Mengalirkan lumpur menuju kelubang pemasukkan digester. Untuk lebih mudahnya dalam memasukkan lumpur ke dalam digester yaitu kran gas yang berada di atas digester harus dibuka terlebih dahulu dan udara yang ada didalam digester pun akan mendesak keluar. Untuk pengisian yang pertama harus membutuhkan banyak lumpur sehingga volume di dalam digester terisi penuh.

3. Lakukan penambahan starter yang jumlahnya 1 liter dan isi rumen segar dari rumah potong hewan yang jumlahnya sebanyak 5 karung untuk kebutuhan kapasitas digester 3,5 sampai 5,0 $\mathrm{m}^{2}$. Setelah digester terisi penuh oleh lumpur, kran gas pada digester harus ditutup sehingga terjadi proses fermentasi.

4. Buanglah gas yang pertama dihasilkan pada hari ke 1 sampai hari ke 8. Pada hari ke 10 hingga hari ke 14 akan terbentuk gas metana $\left(\mathrm{CH}_{4}\right)$ dan gas $\mathrm{CO}_{2}$ dan sudah mulai menurun dalam fermentasi tersebut. Pada hari ke 14 maka akan terbentuk gas yang dapat menyalakan api pada kompor gas.

Proses pembentukan biogas dibagi menjadi tiga tahapan, yaitu:

1. Tahap Hidrolisis (Hydrolysis)

Di tahap ini, bakteri memutuskan rantai panjang karbohidrat kompleks; protein dan lipid menjadi senyawa rantai pendek. Contohnya polisakarida diubah menjadi monosakarida, sedangkan protein diubah menjadi peptide dan asam amino.

2. Tahap Asidifikasi (Asidogenesis dan Asetogenesis)

Pada tahap ini, bakteri(Acetobacter aceti) menghasilkan asam untuk mengubah senyawa rantai pendek hasil proses hidrolisis menjadi asam asetat, hidrogen, dan karbon dioksida. Bakteri tersebut merupakan bakteri anaerob yang dapat tumbuh dan berkembang dalam keadaan asam. Bakteri memerlukan oksigen dan karbondioksida yang diperoleh dari oksigen yang terlarut untuk menghasilkan asam 
asetat. Pembentukan asam pada kondisi anaerobik tersebut penting untuk pembentukan gas metana oleh mikroorganisme pada proses selanjutnya. Selain itu bakteri tersebut juga mengubah senyawa berantai pendek menjadi alkohol, asam organik, asam amino, karbon dioksida, hidrogen sulfida, dan sedikit gas metana.Tahap ini $\mathrm{C}_{6} \mathrm{H}_{12} \mathrm{O}_{6} \rightarrow \quad 2 \mathrm{C}_{2} \mathrm{H}_{5} \mathrm{OH}+$ $2 \mathrm{CO}_{2}+2 \mathrm{ATP}(-118 \mathrm{~kJ}$ per mol) termasuk reaksi eksotermis yang menghasilkan energi.

3. Tahap Pembentukan Gas Metana (Methanogenesis)

Pada tahap ini, bakteri Methanobacterium omelianski mengubah senyawa hasil proses asidifikasi menjadi metana dan $\mathrm{CO}_{2}$ dalam kondisi anaerob. Proses pembentukan gas metana ini termasuk reaksi eksotermis.

Proses pembuatan biogas dengan menggunakan biodigester pada prinsipnya adalah menciptakan suatu sistem kedap udara dengan bagian-bagian pokok yang terdiri dari tangki pencerna (digester tank), lubang input bahan baku, lubang output lumpur sisa hasil pencernaan (slurry) dan lubang penyaluran biogas yang terbentuk. Dalam digester terkandung bakteri metana yang akan mengolah limbah organik menjadi biogas. Sisa limbah dari biogas tersebut dapat dibuat menjadi pupuk kompos.

Penggunaan kotoran sapi sebagai suatu inisiasi pembuatan biogas sangatlah diperlukan oleh masyarakat, termasuk di Desa padamara yang telah dilakukan sebuah percontohan pembuatan biogas dari kotoran Sapi oleh Mahasiswa KKN Universitas Mataram. Dalam proses pengolahan biogas tersebut para mahasiswa menggunakan digester sementara yang berlokasi di kandang kolektif desa Padamara. Proses pembuatan biogas memakan waktu kurang lebih 4-5 minggu dan baru menghasilkan gas dengan tekanan yang kecil, aman digunakan dan akan sangat bermanfaat jika terus di kembangkan oleh masyarakat desa. Adapun langkah-langkah yang telah dilakukan oleh mahasiswa KKN Unram yaitu dengan memberikan penyuluhan kepada masyarakat desa bekerjasama dengan pihak Balai pengkajian Teknologi Pertanian sebagai pemateri dimana penyuluhan dilakukan ke dalam dua tahap yaitu tahap awal perkenalan tentang cara pembuatan dan manfaat biogas selanjutnya tahap kedua penyuluhan tentang hasil dari biogas tersebut kepada masyarakat dengan menggunakan instalasi sementara yang digunakan sebagai sampel.

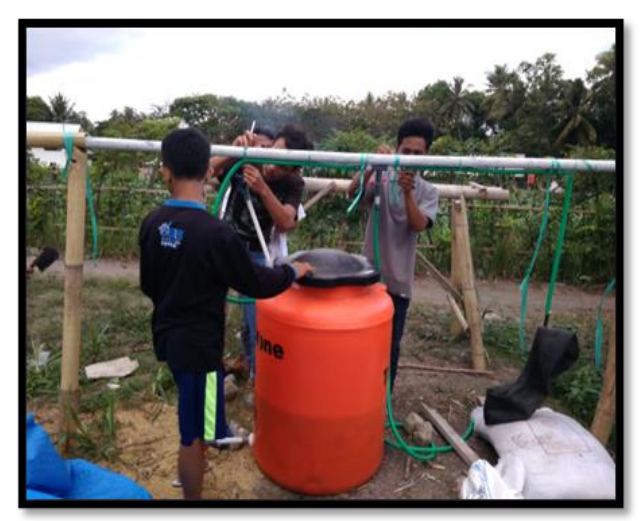

Gambar 1. Instalasi Biogas Sementara

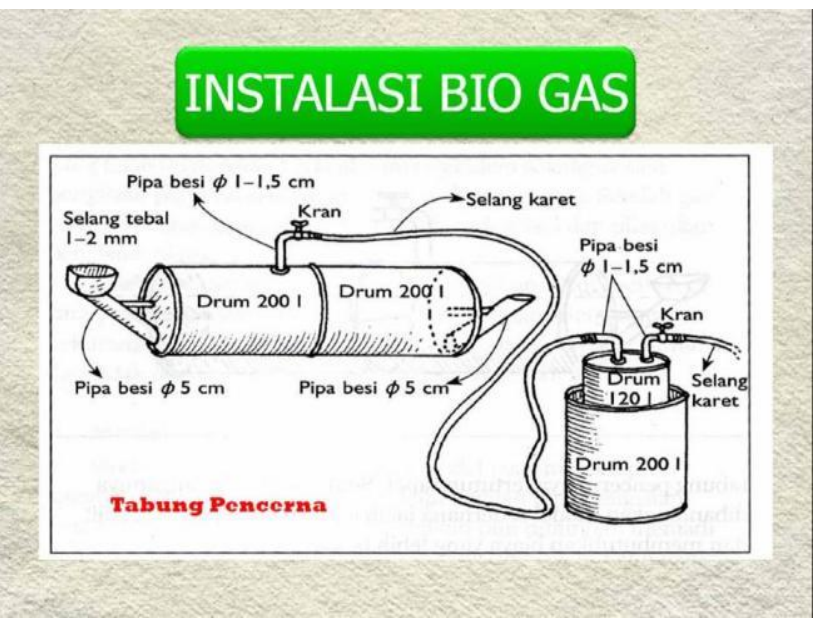

Gambar 2. Instalasi Biogas Permanen
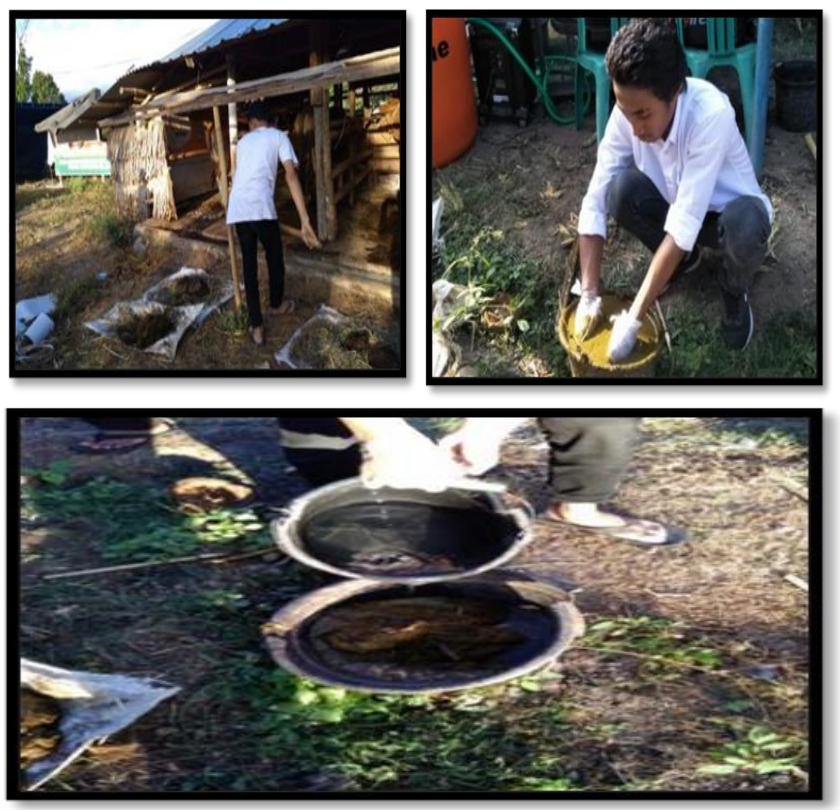

Gambar 3. Proses Pengolahan Kotoran Sapi menjadi Biogas 


\section{b. Pemanfaatan Kotoran Sapi Menjadi Pupuk Kompos}

Pupuk Kompos merupakan pupuk organik yang berasal dari sisa tanaman dan kotoran hewan yang telah mengalami proses dekomposisi atau pelapukan. Selama ini sisa tanaman dan kotoran hewan tersebut belum sepenuhnya dimanfaatkan sebagai pengganti pupuk buatan. Kompos yang baik adalah yang sudah cukup mengalami pelapukan dan dicirikan oleh warna yang sudah berbeda dengan warna bahan pembentuknya, tidak berbau, kadar air rendah dan sesuai suhu ruang. Pupuk kompos bermanfaat untuk menambah kesuburan tanah. Karena adanya penambahan unsur hara, humus, dan bahan organik ke dalam tanah menimbulkan efek residual, yaitu berpengaruh dalam jangka panjang sehingga sifat fisik dan kimia tanah diperbaiki. Pemberian pupuk organik menyebabkan terjadinya perbaikan struktur tanah. Akibatnya sifat fisik dan kimia tanah ikut diperbaiki. Sifat biologi tanah dapat diperbaiki dan mekanisme jasad renik yang ada menjadi hidup.Pendapat beberapa ahli menyebutkan bahwa pemberian pupuk organik akan meningkatkan populasi musuh alami mikroba tanah sehingga menekan aktivitas saprofitik dari patogen tanaman. Keamanan penggunaannya dapat dijamin. Pupuk organik tidak akan merugikan kesehatan ataupun mencemari lingkungan.

Adapun bahan-bahan yang dibutuhkan untuk membuat pupuk kompos dari kotoran sapi yaitu:

1. Kotoran sapi (kering) minimal $80-83 \%$ dan lebih bagus jika bercampur dengan urin

2. Serbuk gergaji atau sekam atau jerami

3. Abu dapur $10 \%$

4. Kapur pertanian $2 \%$

5. Bahan pemacu mikroorganisme (Stardec) $0,25 \%$.

\section{Cairan EM4}

Setelah semua bahan tersedia, saatnya lakukan langkah-langkah pengomposan. Cara membuat adalah seperti di bawah ini:

1. Campur semua bahan yang dibutuhkan untuk pembuatan pupuk kompos yaitu kotoran sapi, serbuk gergaji, abu dan kapur dengan merata. kemudian tumpuk di tempat yang terlindungi dari sinar matahari dan hujan secara langsung. Akan lebih baik jika ditumpuk di tempat pembuatan pupuk kompos yang khusus. Biarkan selama 1 hari.

2. Besoknya aduk tumpukan bahan kompos kemudian taburi menggunakan stardec, aduk sampai merata. kemudian tumpuk lagi dengan ketinggian minimal $80 \mathrm{~cm}$.

3. Biarkan tumpukan terbuka sampai 7 hari , namun harus tetap dijaga agar terhindar dari panas dan hujan. Pada hari ke 7, balik tumpukan agar memasok oksigen bisa masuk ke dalam bahan dengan merata. Oksigen dibutuhkan untuk aktivitas mikroba. Pambalikan bahan dilakukan setiap 7 hari sekali.

4. Aktivitas mikroba bisa ditandai dengan adanya peningkatan suhu. Biasanya peningkatan suhu terjadi menjelang hari ke 8 sampai hari ke 21 . Pada hari ke 28 suhu akan menurun kembali. Kenaikan suhu yang terjadi bisa sampai 300oC. Suhu yang tinggi ini akan membuat pupuk kompos menjadi steril dari bibit gulma dan bakteri patogen.

5. Campuran kotoran sapi itu sudah menjadi pupuk kompos jika suhu telah netral dan warnanya hitam kecoklatan.

6. Campuran itu kemudian didiamkan beberapa hari untuk proses penguraian. Untuk penguraian tergantung cuaca. Untuk cuaca kering biasanya membutuhkan waktu tiga pekan, sedangkan saat musim hujan lebih lama lagi, yaitu selama enam pekan. Selama proses penguraian, juga harus dibolak-balik, yaitu satu kali seminggu pada musim kering dan saat musim hujan sekali dalam dua Minggu. Untuk pembalikan ini dilakukan tiga kali

\section{c. Prinsip pembuatan kompos}

1. Menjaga Kelembaban

Kelembaban berperanan penting dalam proses pembuatan kompos dan mutu kompos. Kelembaban optimum adalah 50-60 \%. Rendahnya kelembaban udara menurunkan proses penguraian, bila terlalu tinggi menghambat aliran udara.

2. Pembalikan

Pembalikan diperlukan agar kompos tidak kekurangan udara dan mempercepat proses penguraian. Proses penguraian akan berjalan lambat jika kompos kekurangan udara. 


\section{Peneduh}

Agar proses penguraian bahan organik berlangsung sempurna usahakan tempat pembuatan kompos terlindung dari hujan dan sinar matahari secara langsung. Karenanya tempat kompos perlu dibuatkan pelindung.

Setelah penguraian, kotoran sapi yang sudah menjadi pupuk kompos itu selanjutnya digiling sebelum dikemas masih membutuhkan pengayaan lagi agar teksturnya halus. Lalu dikemas dan disalurkan kepada masyarakat khususnya petani.

Pembuatan pupuk kompos pun telah dilakukan oleh kelompok KKN Desa Padamara 2018, dimana pupuk kompos dijadikan sebagai salah satu program kerja utama. Pengolahan pupuk kompos sama halnya dengan biogas dengan memanfaatkan kotoran sapi. Langkah-langkah yang dilakukan pun hampir sama yaitu dengan mengadakan penyuluhan sebanyak dua kali dengan mitra yang sama yaitu Balai Pengkajian Teknologi Pertanian. Dalam proses pengolahan pupuk kompos, Kelompok KKN Padamara menggunakan galian sebagai wadah yang kemudian semua bahan terdiri dari kotoran sapi, cairan $\mathrm{EM}_{4}$, kapur, sekam, yakult (sebagai perangsang mikroba), yang kemudian ditutup secara rapat selama dua hari kemudian, dibolak balik setiap dua hari sekali hingga melebur dan sepenuhnya menjadi pupuk setelah 35 hari. Setelah pupuk tersebut telah jadi kemudian dikemas dan dibagikan masyarakat sebagai sebuah sampel yang kemudian dapat ditiru dan memberikan keuntungan bagi masyarakat di desa Padamara tersebut.

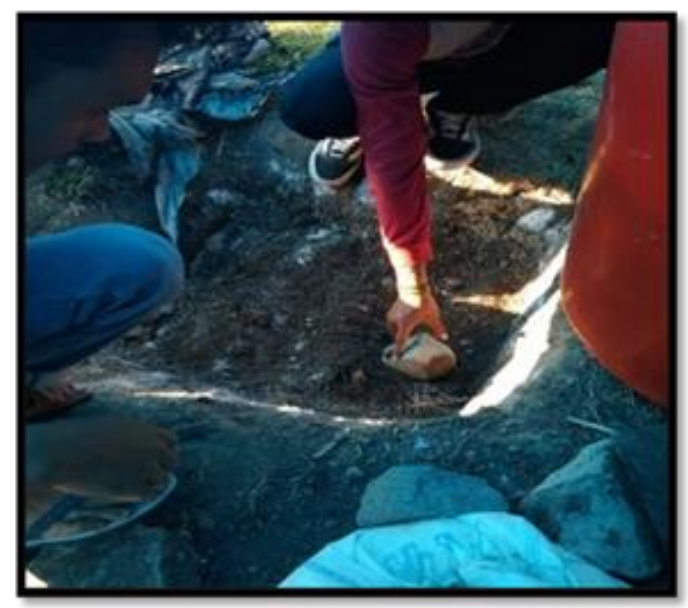

Gambar 4. Proses Pembuatan Pupuk

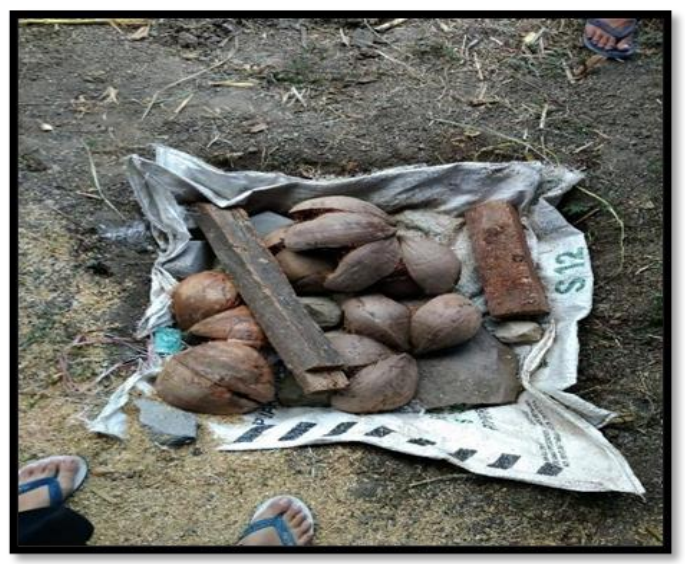

Gambar 5. Pupuk Ditutup Dengan Rapat

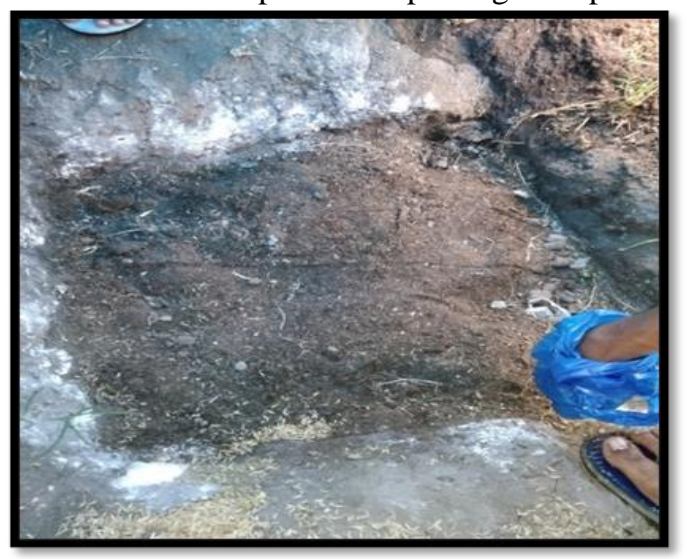

Gambar 6. Pupuk yang Telah Jadi

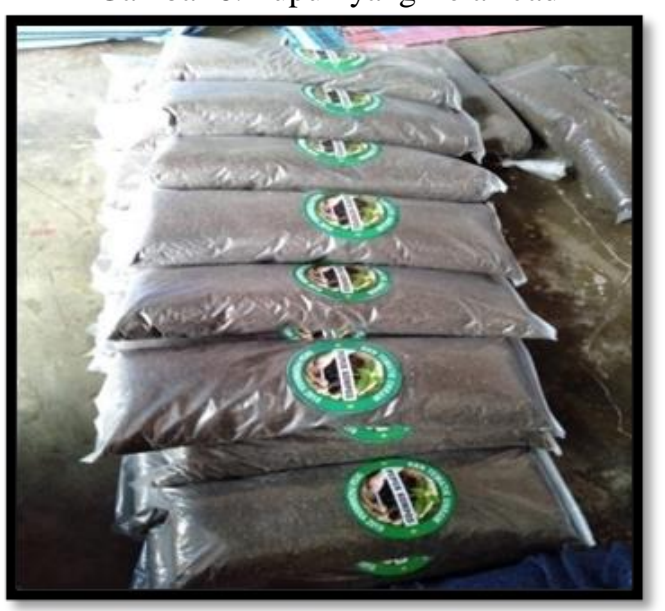

Gambar 7. Pupuk Telah Dikemas

\section{Kesimpulan}

Kotoran sapi yang dianggap menjadi limbah dan sering meresahkan masyarakat ternyata memiliki potensi dan nilai yang sangat bermanfaat bagi kehidupan manusia. Jika diolah dengan baik kotoran sapi dapat dijadikan beberapa hal yang bermanfaat yaitu biogas dan pupuk kompos. Biogas 
sebagai sebuah inisiasi energi terbarukan yang sangat diperlukan dalam kehidupan manusia yang mana selain bernilai ekonomis, juga menciptakan dunia yang hemat energi. Selain itu kotoran sapi jika dijadikan pupuk Kompos juga memiliki potensi yang sangat berguna untuk menjaga kesuburan tanah dan menciptakan hasil panen yang maksimal dalam dunia pertanian.

Kelompok KKN Padamara 2018 telah melakukan sebuah pemberdayaan masyarakat dengan memanfaatkan kotoran sapi yang pada mulanya dianggap sebagai masalah kini menjadi potensi yang akan sangat berguna dalam kehidupan masyarakat desa, yang mana dengan mengolah kotoran sapi tersebut menjadi biogas dan pupuk kompos. Tentunya inisiasi ini diharapkan dapat memberikan kesadaran kepada masyarakat bahkan kotoran sapi yang dianggap sebagai masalah ternyata memiliki potensi yang sangat luar biasa, oleh karena itu diharapkan kepada masyarakat dengan adanya pemberdayaan tersebut masyarakat dapat tergerak dan kemudian melanjutkan pengolahan kotoran sapi menjadi biogas dan pupuk kompos sehingga akan memberikan keuntungan bagi masyarakat desa Padamara.

\section{Ucapan Terima Kasih}

Ucapan terima kasih setinggi-tingginya kami sampaikan kepada pihak-pihak yang telah membantu pelaksanaan kegiatan pelatihan ini, terutama pada Bapak Rektor Unram, Ketua Lembaga Pengabdian kepada masyarakat Unram, mahasiswa yang terlibat dan Kepala desa beserta staf, Masyarakat Desa Padamara Lombok Timur yang senantiasa membantu dan menemani kami dalam pelaksanaan kegiatan pengabdian kepada masyarakat ini.

\section{Daftar Pustaka}

Anonim. "Petunjuk Pembuatan Pupuk Organik/ Kompos". Universitas Muhammadiyah Palembang: Palembang

Aprianti, Y. 2005. Andrias Wiji Setio Pamuji: Penemu reaktor biogas. Kompas: Jakarta.

Hartmann, H. dan B. K. Ahring. 2005. "The future biogas productions". http//www.risoe.dk /rispubVSYS/syspdf/energconf05/session6 hartmann.pdf.
Purwendro, Setyo. 2009. Mengolah Sampah: untuk Pupuk dan Pestisida organic. Penebar Swadaya, Jakarta

Rasti, Diah. Dkk. 2012.“KOMPOS”. Litbang E-book pada balitanah.litbang.pertanian.go.id

Soepardjo, A.H. 2005. Energi baru dan terbarukan. Kompas: Jakarta

Sutanto, R. 2002. Pertanian Organik: Menuju Pertanian Alternatif dan Berkelanjutan. Penerbit Kanisius. Yogyakarta. 